\title{
The Segmentation of Local Television Audiences in Central Java in the Digital Era
}

\section{Segmentasi Audiens Televisi Lokal di Jawa Tengah pada Era Digital}

\author{
Warto $^{1}$ \\ ${ }^{1}$ Faculty of Da'wa, IAIN Purwokerto, J1. A. Yani No. 40-A Purwokerto, \\ Central Java 53115, Indonesia \\ *Corresponding author, e-mail: warto@iainpurwokerto.ac.id
}

\begin{abstract}
This theme of this article is the audiences segmentation by local television in Central Java. This study is motivated by the large amount of number of local television stations that have sprung up, as the digital era progresses. This study uses qualitative descriptive approach with the sample of five television stations, namely Banyumas TV, Semarang TV, TVKU Semarang, Simpang5 TV Pati, and also Ratih TV Kebumen. The target of the audiences segmentation demographically is the people aged 30 years and above, except TVKU Semarang, namely teenagers and students aged 15-25 years. The development in the digital era is now an opportunity to maintain the existence of local television by doing convergence of digital media. The concept of 'Think Global Act Local' is the opposite in the local television industry to become 'Think Local Act Global', for the broadcasting world if they still want to exist in the digital media.
\end{abstract}

Keywords: Audiences Segmentation, Local Television, Think Local Act Global, Digital Era.

\begin{abstract}
Abstrak
Artikel ini mengangkat tema segmentasi audiens televisi lokal yang ada di Jawa Tengah. Penelitian ini dilatarbelakangi oleh banyaknya stasiun televisi lokal yang bermunculan, disaat era digital semakin maju. Penelitian ini menggunakan pendekatan deskriptif kualitatif dengan sampel lima stasiun televisi, yaitu Banyumas TV, Semarang TV, TVKU Semarang, Simpang5 TV Pati, dan juga Ratih TV Kebumen. Segmentasi audiens secara demografis yang disasar yaitu masyarakat dengan usia 30 tahun ke atas, kecuali TVKU Semarang yaitu remaja dan mahasiswa berumur 15-25 tahun. Perkembangan pada era digital sekarang ini menjadi peluang untuk mempertahankan eksistensi televisi lokal dengan melakukan konvergensi media digital. Konsep 'Think Global Act Local', berlaku sebaliknya dalam industri televisi lokal menjadi 'Think Local Act Global', untuk dunia penyiaran jika ingin tetap eksis di media digital.
\end{abstract}

Kata Kunci: Segmentasi Audiens, Televisi Lokal, Think Local Act Global, Era Digital.

\section{Introduction}

Television has become one of the most preferred media by the people. Television is the main media consumed by the Indonesian people up to $95 \%$, compared to radio which is only $20 \%$ and printed media (newspapers, tabloids, and magazines) with a total of 23\% (Nielsen, 2014). Starting from children to adults spend time in front of the television with an average of 4.5 hours each day (Berita Satu, 2010). Various events presented by many television stations, make the people feel at home in front of the screen for hours. Television provides a stimulus to the auditory sense of vision simultaneously so that it greatly affects the memory of the brain which in turn can cause addiction, like alcoholism that can damage physically and mentally (Sussman \& Moran, 2013).

Even though it has potential social problems that are quite serious -- for example ethics violations of deontology, theology and primacy -- (Setiawan, 2010), the 
development of television in Indonesia has not receded, but vice versa. The more recent, the more television stations popping up nationally and locally. We can see the number of national television stations long before the reform era, there was only TVRI. Then towards the reformation era in the $90 \mathrm{~s}$, several national private televisions appeared, RCTI, SCTV, Indosiar and ANTV, where television at that time had reached 14 million units in the homes of Indonesian citizens (Handayani, 2010). After the reformation era, which became the gateway to freedom on all sectors including the television mass media line by the emerging of many national television stations which until now have reached 15 television stations.

Not to mention the many emergence of networked television that adds to the many television listings in Indonesia. Even the paid subscription television has at least 19 that can be chosen by the Indonesian people. The subscription television does not only broadcast exclusive channels from abroad, but there is also an inhouse channel obligation that must be provided. So that it adds a lot of channel choices that can be enjoyed by the viewers. Community television whose presence is also recognized and protected by the Act also appears and mushroomed throughout Indonesia. Many community organizations set up community television for 'their own community', but the broadcasts can also be enjoyed by the public. The existence of these community television stations further adds to the television list in Indonesia and certainly becomes an alternative choice of viewers which might be able to happen by the national TV shows that tend to be hegemony and capitalist.

Meanwhile, because of the issue of digital TV through the Decree of the Minister of Communication and Information Number: 07/P/M.KOMINFO/3/2007 dated March 21, 2007 concerning Digital Terrestrial Broadcasting Standards for Non-Mobile Television in Indonesia ('Standar Penyiaran Digital Terestrial untuk Televisi Tidak Bergerak di Indonesia'), it is a heavy burden for the local television organizers which incidentally has smaller broadcast range and audiences than national television. In order to meet these regulations, local television must prepare a large amount of funds, ranging from 1 billion to 7 billion which becomes the guarantee money to be able to broadcast digitally (Prabowo, 2012). This is certainly not a small burden for the local television stations with limited capital because they only rely on local investors.

Several previous studies of similar themes have been carried out related to local television from various perspectives. Among other things, Priyowidodo conducted research on measuring the strength and the excellence of the local television industry in the era of autonomy (Priyowidodo, 2008). Priyowidodo stated that the era of regional autonomy which blew in the early days of the reformation gave fresh air to television. Until 2009, there were about two hundreds local television in various cities in Indonesia. The enthusiasm of the establishment of local television appeared similar to when the rise of the regional government established radio stations belonging to the local government.

The few conglomerates who have at the same time several national television stations are suspected to be the cause of the oligopoly of information in the community (Priyowidodo, 2008). The communities are nationally fed by less-quality programs such as soap operas and the advertisements that campaign for consumerism. Directly or indirectly, in the name of capitalism, people become the victims and the objects that are exploited to get maximum material advantages. Unfortunately, these benefits are only enjoyed by a small group of wealthy people in Indonesia.

Prabowo criticized government policies regarding the obligation of television stations to switch to the digital broadcast system (Prabowo, 2012). He questioned the 
policy, whether it was the spirit of developing or the suppression of local television and the community. Because the fact was that the costs incurred for migrating from analog to digital were not cheap, while local television and community financial capabilities were very limited. Another point of view that is slightly different, Sudarmawan had conducted research on the opportunities and the challenges of local television business after the regulation of networking television (Sudarmawan, 2007). Government regulations regarding networking television make it possible for local television to collaborate with national television, so that capital constraints can be supported by national television through this collaboration.

The researches related to television segmentation have also been conducted, among others, by Cahayadi (2017); Munanjar (2017); Rosiatun (2010); Soffa (2013); Wiska \& Lukman (2014) (and several other researchers). Some of these studies discussed the segmentation carried out by only one television station, or the study conducted by Jaya, (2016); Munanjar (2017); Rosiatun (2010); Soffa (2013) which discussed the more conical segmentation at an event on a television station (Jaya, 2016; Munanjar, 2017; Rosiatun, 2010; Soffa, 2013). Whereas, the research conducted by the current researcher has broader range of areas, to observe the characteristics of several segmentations carried out by several television stations in the scope of Central Java. The scope of this research can see which television stations have good segmentation so that they can survive in the era of digital media. Managers of local television stations must be prepared to compete to grab the attention of the audiences, because of the increasingly fierce competition in the television industry (N.A., 2002). For example, in one provincial city there are several local televisions, so it must compete with national television stations, subscription television, networking television and community television in the city. Local television stations must be able to broadcast interesting programs to the public or audience so as not to be left out.

In the midst of increasingly fierce competition among televisions, other competitors emerge that are no less interesting in the audience community, namely digital media. Internet-based digital media presents a variety of entertainments that can always be accessed whenever and wherever. Using a practical gadget that can be carried everywhere and the cheaper data rates promise entertainments that can be accessed by all segments of society. Internet-based digital media has become an alternative cjoice media in the midst of the intense competition among national television, local television, networking television, subscription television, and community television. With these changes, the the audiences become more active in taking selective media actions that they consume (Malau, 2011).

Table 1. The List of Local Televisions in Central Java

\begin{tabular}{ccc}
\hline No & Name of Television & Regency/ City \\
\hline 1. & TVRI Jawa Tengah & Semarang \\
2. & TVKU & Semarang \\
3. & Semarang TV & Semarang \\
4. & TA TV & Surakarta \\
5. & Ratih TV & Kebumen \\
6. & Banyumas TV & Purwokerto \\
7. & Satelit TV & Purwokerto \\
8. & Simpang5 TV & Pati \\
9. & Batik TV & Pekalongan \\
10. & Grabak TV & Magelang \\
\hline
\end{tabular}




\begin{tabular}{ccc}
\hline 11. & MAJT TV & Semarang \\
12. & Magelang TV & Magelang \\
13. & Temanggung TV & Temanggung \\
14. & Jepara TV & Jepara \\
15. & Purworejo TV & Purwokerjo \\
16. & Salatiga TV & Salatiga \\
17. & Solo TV & Surakarta \\
18. & ISI TV & Surakarta \\
19. & MTATV & Surakarta \\
\hline
\end{tabular}

There are at least 19 local television stations in Central Java spreading across several regions/cities. In fact, as seen in table 1, certain regions have several local television stations (Kementerian Komunikasi dan Informasi Republik Indonesia, 2017; Priyowidodo, 2008). Television certainly can not target all segments of society as the audiences. In order to be more focused in designing the program, the audiences that have not been widely explored by national television or subscription and networking television must be chosen. Based on the researchers' observations, local televisions are more able to uphold broadcasting idealism, compared to national televisions which tend to be capitalist and make rating as 'new God'. So whatever programs aired on national television should be able to produce a high rating, even though most of them are trash shows which do not educate. One of the local television superior program is local news which presents activities that are close to the local community, thus the community feels closer and possessing. This is because people are always or interested and have information needs around their homes (Claretta, 2012).

Various efforts have been conducted by local television in Central Java to maintain their existence in the digital era. These efforts include making social media accounts Facebook, Twitter, Instagram, and the like. Besides that, it also provides footage that is uploaded on Youtube. In fact, some televisions have been facilitated with streaming TV facilities through websites or applications that can be downloaded in Playstore and Appstore. The presence of the digital era is not being addressed as a competitor, but the opportunity to further disseminate broadcasts to all corners of the world. Audience segmentation according to Kertajaya is the art of identifying and capturing various market opportunities (Kertajaya, 2006). Therefore it requires carefulness of how local television management identifies the market through the right segmentation of the audiences. Because of the vast extent of the society, the management of local television needs to aim precisely so that it can deliver shows that are appropriate for the audiences. More explicitly, Rhenald Kasali emphasized that segmentation was done to undermine the competitor's market (Kasali, 1998).

If they can properly segment their audiences, they will not only be able to maintain their existence, but also more than that, they can undermine the market of competitors, in this case is the market of digital television viewers. With a variety of problems and challenges faced by local television, starting from competition with national television, government regulations on digital television, to competition with digital media that continues to grow, local television needs to do the right segmentation and audiences so that the local television industry can still survive and develop in the competition.

\section{Methodology}

This study uses qualitative descriptive research type with case study approach. Data collection technique uses purposive sampling by choosing television stations that have 
different characteristics. The data were explored through in-depth interviews which were then triangulated with observation resilts and theories about segmentation. The subject of this study is the manager of local television station in the Central Java region, while the object of the research is the segmentation process that has been carried out by the manager of the television station.

The researcher conducted in-depth interviews with interview instruments to help keep the focus on the research theme. The interviews were conducted at several stations in the city of Semarang. The interviews were conducted at TVKU Television Station with Marketing Manager, Simpang5 TV with the Director, Banyumas TV with the Director, Semarang TV with the Director and also Ratih TV Kebumen with the Operations Manager. In addition to interviews, observations were also made on social media accounts, Youtube channels, and applications downloaded in the AppStore and Playstore, as shown in Table 2. The observations were conducted to obtain data on the extent of penetration by television stations in facing the digital era.

Table 2. The List of Local Television Channels in the Digital and Social Media Accounts on Local Television

\begin{tabular}{cccccccc}
\hline $\begin{array}{c}\text { TV } \\
\text { Station }\end{array}$ & Website & Streaming & $\begin{array}{c}\text { YouTube } \\
\text { Channel }\end{array}$ & Facebook & $\begin{array}{c}\text { Google } \\
\text { Play/ } \\
\text { Appstore } \\
\text { Application }\end{array}$ & Instagram & Twitter \\
\hline $\begin{array}{c}\text { Semarang } \\
\text { TV }\end{array}$ & $\begin{array}{c}\text { Doesn't } \\
\text { have }\end{array}$ & $\begin{array}{c}\text { Doesn't } \\
\text { have }\end{array}$ & Has & Has & Has & Has & Has \\
TVKU & Has & Has & Has & Has & Has & Has & Has \\
$\begin{array}{c}\text { Simpang5 } \\
\text { TV }\end{array}$ & Has & Has & Has & Has & Has & Has & Has \\
$\begin{array}{c}\text { Banyumas } \\
\text { TV }\end{array}$ & Has & Has & Has & Has & Has & Has & Has \\
Ratih TV & Has & Has & Has & Has & $\begin{array}{c}\text { Doesn't } \\
\text { have }\end{array}$ & Has & Has \\
\hline
\end{tabular}

The data that have been collected are then analyzed using segmentation concepts belonging to Rhenald Kasali, Hermawan Kertajaya, Philip Kotler, and Ian Dunbar. Of the several segmentation theories, there are many similarities, but there are a number of small things that are conceptually quite different. The use of these several theories is intended to be able to provide comprehensive research results from various perspectives.

\section{Results and Discussion}

Banyumas TV

Banyumas TV is one of the local television broadcasted in the area of the former residency of Banyumas. Starting from the hobby of the owner at that time to electronics and having an electronics store and satellite dish antenna in Purwokerto. The satellite dish antenna sales in the early 1990s surged sharply with the presence of national private television stations such as RCTI, SCTV, Indosiar, and TPI, which could be captured only by satellite dish antennas. But on its way to the early 2000s, the sale of satellite dishes in his store declined sharply because national private television stations began able to be enjoyed through ordinary PF antennas. Then accidentally, Firdaus (Television Director) read the news in a magazine that contained information that the private sector could establish a local television station in their respective regions. Based on this information, the idea emerged to establish a local television station (Banyumas TV) in Banyumas area. 
Banyumas TV which currently has office and studio on Jl. H.R. Boenyamin 106 Pabuwaran North Purwokerto has a vision to explore the potential and to preserve the local culture of Banyumasan. When viewed from the arrangement of broadcast patterns, there are quite a lot of local contents related to culture. For example, the shadow puppet show with the title 'Wakulmas (Wayang Kulit Banyumasan)' becomes favorite program with many viewers broadcasted every Saturday night at $21.00-23.00$. There are many viewers watching because at the beginning of the program it gave an opportunity for viewers to send greetings which was called 'Kintunsalam' for 30 minutes from 9:00 p.m. to 9:30 p.m. But there were few disadvantages, 'Kartun Banyumasan' show which carried the Banyumasan-style comedy theme was not broadcasted anymore. Even though the program was also one of the featured program some times ago.

Simpang5 TV Pati

Simpang5 TV airs on 59 UHF channels with the offices and studios on the PatiKudus 6.5 KM highway Pati. This local television in Pati region is one of the members of Jawa Pos Multimedia (JPM) headquartered in Surabaya. The main objective of the establishment of Simpang5 TV is to raise local potential. To become a local television that is truly capable of becoming a spirit of locality, the local cultures in the form of 'ketoprak', 'ludruk', and 'campur sari' become the main dish at the beginning of the broadcast at the end of 2011 as it had permits from the KPID it aired on 59 UHF channel. Because of the large amount of local contents that were aired, Simpang5 TV was stigmatized and dubbed as 'ketoprak t $v$ ', 'ludruk $t v$ ' and 'campursari $t v$ '. The program division is in charge of hunting, searching, producing and broadcasting Ketoprak and Ludruk in Pati and surrounding districts. The aim is very explicit and clear to revive the typical local culture of Pati, presenting to the public so that the culture is loved and continues to be developed.

Simpang5 TV, which is the JTV Surabaya and Jakarta television network, has an obligation to broadcast network content in the form of national news with a portion of 3.5 hours each day. The remaining 14.5 hours are filled with local content. But on the way, the change in broadcast patterns is quite significant. The portion of cultural shows is fewer, at least those which directly mention the names of typical cultural program such as 'Klik Campursari', 'Stasiun Dangdut', 'Nyampursarinan Live', and 'Ketoprak.' However, due to high production costs, Simpang5 TV cooperates with the ketoprak groups which have documentation for later editing and airing on Simpang5 TV. With this collaboration, the two sides are benefited one another, Simpang5 TV gets broadcast content at low cost and the 'Ketoprak' group gets publication on local television media so that it will be more famous and in demand.

News broadcast aims at the adult segment, where if we borrow the research results of the news broadcast viewers segmentation show the viewers over 20 years reach $89 \%$, while viewers under 20 years are only $11 \%$ of the total respondents as many as 140 respondents (Rosiatun, 2010). The segment of the adult audiences over the age of 20 in Pati region are 801,852 people, more than the population under the age of 20 which only amounted to 389,140 people (Badan Pusat Statistik, 2018). If in Central Java area as the research location, the number of people under 20 years is $11,228,498$ people and those over 20 years are $21,154,159$ people. The segment of the higher age group is those aged 20 years and over.

TVKU Semarang

TVKU Semarang as one of the local private televisions that has existed since December 2004 has a vision of educating the nation through audio-visual media, as well 
as having vision of providing education through television media with theoretical and practical educational materials as well as applicable to the people of Semarang city in particular and Central Java in general. The vision and mission are of course not separated from the birth of TVKU from a well-known university in Semarang which is concerned in contributing to produce reliable human resources in the field of information technology, namely Universitas Dian Nuswantoro (UDINUS). TVKU is one of the media used to contribute significantly to the people of Semarang and surrounding areas by presenting a variety of educational programs, in accordance with UDINUS' core business in the field of higher education. In short, TVKU's vision and mission are Edutainment: that is to offer entertainment-based education. With this edutainment approach, it tries to package educational content more interesting because it is based on audio-visual.

Before analyzing the segmentation of audiences in TVKU Semarang, it will first be explained about the broadcast patterns and the results of interviews conducted on August 21, 2018 in the studio with Deka as TVKU's Marketing manager. When conducting interviews, the broadcast pattern documents that are valid from July 31 to August 6, 2018 were obtained, of course the latest broadcast patterns were presented to TVKU's loyal viewers. TVKU starts broadcasting every day from 04:30 - 00:00 or for 20 hours. The duration is quite long and almost equals to the duration of national television programs.

The opening program was broadcasted every day at 04.30 - 05.30 namely 'MAJT TV', a program of Islamic content from the collaboration between TVKU and the Great Mosque of Central Java (MAJT). The broadcast content from MAJT TV includes Islamic preaching, routine studies, Islamic fables, and information about activities and activities agenda at the Great Mosque of Central Java. MAJT TV programs were also broadcasted on TVKU at 9:00 to 10:00 p.m. MAJT TV content airs on TVKU every day for two hours, one hour in the morning and one hour in the evening. Mutually beneficial cooperation, MAJT TV can broadcast with the help of the existing infrastructure and the extensive broadcast coverage of TVKU. Whereas TVKU has an agenda for the segment of the Islamic community which is the majority in Central Java without the need to make its own event products which of course takes an expensive budget. This symbiosis of mutualism can be created because both parties agree with each other to be able to broadcast religious programs continuously and qualified especially to the people of Semarang. Religious programs on national TV get relatively small portion, even though the Muslim community segment is the largest compared to other religious segments. Even national television almost does not broadcast religious programs in the form of recitals, dialogues, or talk shows at prime time at $21.00-22.00$. TVKU Semarang dared to broadcast it at this hour in the hope that many audiences of Muslim segments would watch it and be able to learn religion from the program.

Semarang TV

Semarang TV is one of the alternative local television in Semarang that chooses the local content segment by promoting cultural programs. In accordance with the vision and mission of exploring and promoting local culture in order to preserve it. Some of the culture that are almost extinct, especially the performing arts, have been restored and revitalized to be aired on Semarang TV. Television which aired since mid-2005 began with Cakra TV which later in 2009 changed to Cakra Semarang TV. In 2012, it joined Bali TV group and the name changed to Semarang TV. Bali TV itself, which is based in Denpasar, has dozens of local television stations located throughout Indonesia, such as those owned by the Jawa Pos Multimedia (JPM) group based in Surabaya. The content of Semarang TV programs as much as $90 \%$ are local programs produced independently by 
Semarang TV crew and management. While 10\% contains programs from Bali TV and several third parties. Semarang TV also has a slogan of Keeping tradition and identity, ready to be a stronghold so that culture remains sustainable amid the current rapid flow of modernization.

Semarang TV broadcast with 10KW transmit power which can reach Semarang, Ungaran, Kendal, Kudus, Demak, Pati, Rembang, Salatiga, North side of Temanggung, Karanganyar and Boyolali. Demographically segment, generally Semarang TV viewers are in their 40s and above. One of the leading programs for this age segment is Nostalgia Fans Club. Even Semarang TV viewers community who liked memories songs in the past was formed. The program that has been waited for by the community is 'Nostalgia Fans $C l u b$ ', where the singers are members of the community. The songs sang are in the form of memorable songs, both domestic and abroad. The program, which is aired every Friday at 8:00 to 9:00 p.m., also has an interactive session, where viewers can send greetings via telephone directly when the program aired. The program which is still similar to 'Nostalgia Fans Club' is Evergreen, which is a memorable song karaoke program and interactive phone every Monday at 8:00 p.m. to 9:00 p.m.

Like local TV in other regions, news content in Semarang TV is also a superior one that is seen by many viewers. In the morning there is 'Seputar Jawa Tengah Pagi' every day at 07.30-08.00 a.m, 'Seputar Jawa Tengah Siang' at 11:30-12.00 a.m, and 'Seputar Jawa Tengah Malam' at 18.30-19.00 p.m. Specifically on Sundays, 'Seputar Jawa Tengah Siang' is replaced with the broadcast of 'Jateng Sepekan' which contains news and information about Central Java that is being hot in the recent week. In addition, there is also Javanese news program that is broadcasted every Monday to Saturday at 08.00-08.30 a.m with the program name 'Sugeng Enjang.' While the Javanese news broadcasted at night from 19.30-20.00 p.m only on Monday, Tuesday, Thursday, and Friday. Semarang TV also broadcasts 'Breaking News' four times a day with the duration of three minutes at 09.00 a.m, 10.00 a.m, 14.00 p.m and 16.00 p.m. The special news feature for residents of Solo Raya is also aired twice a week on Monday at 19.05-19.30 p.m and Saturday at 15.30-16.00 p.m.

Semarang TV with the slogan 'Keeping Tradition and Identity ('Jaga Tradisi dan Jati Diri')' presents a variety of programs that are relevant to the slogan. Many tradition theme programs including 'Wayang Kulit Berseri' every Sunday at 14:00 p.m.-14:30 p.m., then 'Gending Jawa' airs every night at 10:30 p.m. to 11:00 p.m., followed by 'Langen Budaya' at 23:00-24:00 p.m., except on Sundays, which are filled with programs entitled 'Mystery.'

The pattern of program that is quite unique, is at 7:00 a.m., 08:30 a.m., 17:00 p.m., and 18:00 p.m., every day which is filled with different programs, it can be said to be very varied. At 7:00 a.m. to 7:30 a.m. alternately every day is filled with the 'Tokoh dan Koma' program. 'Koma (Komunitas Mania)' is a program that examines the existing community profile in Semarang and its surrounding. Some of the communities that are discussed include the CSR (Charade Semarang Reborn) Community, 'Komunitas Satu Atap', KTCI ('Komunitas Toyota Calya Indonesia') Community, Easy Tricking Community, and others. These programs are as place of existence for the Semarang local community and is one of the local content favored by Semarang TV viewers. While the program entitled 'Tokoh' is a reality show by presenting one of the figures who is then peeled his profile. Ratih TV Kebumen

Of several televisions studied, Ratih TV Kebumen is the only television that operates under the control of the regional government. Ratih TV Kebumen is owned by 
the Kebumen Regency Government whose management is handed over to the Head of Broadcasting Services at the Ministry of Communication and Information. The structure is quite slim, led by a President Director. Under the President Director there is the General Director who oversees two people, namely the Administrative and Finance Head and the Marketing Department. Furthermore, the Operational Director supervises the Head of the Program and Broadcasting, the Head of the News Agency, and the Head of the Engineering Section. Besides Ratih TV Kebumen, in the same building also operates a local government radio broadcast called In FM radio.

As a red plate television owned by the regional government, Ratih TV Kebumen has a vision of becoming a media for public transparency and participation. Besides that, it has mission to strengthen public transparency and participation; to realize broadcasts that encourage the realization of good local governance, to encourage competitive regional investment; and to increase the competitiveness of local potential. From that vision and mission, it becomes the guideline in arranging programs that are broadcasted to the public. Seen in general, the programs shown are local contents. It starts at 10:0010:30 a.m by broadcasting 'Selamat Malam Kebumen' which is re-broadcast of the evening news.

At 11:00 a.m. to 1:00 p.m. presenting various programs which were the relay from national and Central Java TVRI, in fact both are state televisions. At 1:00 p.m.-1:30 p.m. it returns to local content by displaying 'Berita Kebumen' which is re-broadcast news that have been broadcasted previously. The news program is back at 8:00 p.m. to 9:00 p.m., namely 'Berita Indonesia', which is the result of the collaboration between Ratih TV Kebumen and Antara News Agency. The program airs every Monday to Sunday. At 13.30-14.00 is the collaboration program with Antara TV that is 'Mata Indonesia'. All programs from 10:00 - 14:00 are broadcasted every Monday to Sunday. The next program is 'How To Make The Things' which is a collaborative program with Indonesian Tender. At 2:30 p.m. - 3:00 p.m. a special program covering the business of MSMEs in Kebumen region under the name 'Warta UMKM'.

Audiences Segments Targeted by Local Television

Based on the vision and mission of local televisions, most want to raise local contents in order to preserve the noble traditional culture of ancestral heritage. While connoisseurs of the noble traditional culture are getting less because they are eroded by the hedonic modern culture, then the actual segmentation of local television at the age of 25 years and over will be less and less because people at that age are increasingly depleted by age. If we don't think about it right now, then in the long run if we don't aim at the child or adolescent segment, of course the viewer will be increasingly left behind us. If we observe, the nostalgic shows with segments of parents over 40 years old become the leading local television. But if the generation has run out, it is certain that the program will not air again. This is only a prediction, but if local television innovates the program for the youth segment, the researcher believes that in the future it will still exist. The segmentation carried out by TVKU Semarang seems the most realistic target the youth segment.

On one hand, local television becomes a savior for the preservation of local culture, but on the other hand there are fewer segments that like local culture. Thus the audiences segment also decreases. It takes hard work to create a cultural genre program that can be sought after by the teenagers segment so that teenagers can enjoy it in accordance with their youthful enthusiasm. Media convergence absolutely must be done by local television so that it can be enjoyed from various gadgets. The steps taken by TVKU Semarang and 
Simpang5 TV Pati should be imitated by creating an application that is placed in Google Play and Appstore marketplace so that it can be enjoyed from the gadgets.

In general, there is no local television that targets specific audience segment according to market segmentation for goods or services, even though the segmentation itself can be seen from the television programs aired (Rhenald Kasali, Hermawan Kertajaya, Philip Kotler, and Ian Dunbar). For example, news program for the adult segment, cartoon films for children, music shows for teenagers. Of the many local televisions in Central Java, TVKU Semarang has more specific segment than other local televisions that target all segments. Judging from the broadcast pattern or program presented, TVKU Semarang is more targeted at the youth and school age segments. This is quite reasonable because indeed the birth of TVKU Semarang is from a well-known private university in Central Java (UDINUS), and up to present it has studio in campus.

It has recently been collaborating with the SMNetwork (Suara Merdeka Group) that makes it has program for the young that tend to be mature professional segment, for example 'Jago Bisnis' program which is broadcasted live. Semarang TV as a local television station in Semarang does not seem too worried about the existence of TVKU, because indeed the targeted segment is very different. The difference is clearly seen from the program presented which is seen in the television broadcasting pattern. In terms of vision and mission, the slogan also reflects the different segments.

Ratih TV Kebumen as a local television owned by the district government financially has no problems, but the format of the broadcast program still relay from other television stations so that the broadcast originality is still inferior to private local television stations. Media convergence through online media also has not been exploited maximally. Apart from the programs uploaded in online media, promotions and sharing must also be done through online social media, for example through various Whatsapp groups.

In general, all local television stations are not worried about the presence of online media, instead they use the media to converge, but indeed some television stations have not done it maximally, as shown in table 2. For example, Semarang TV does not have an application that can be downloaded on a gadget, likewise, Ratih TV Kebumen. In the format of the program all local television stations have raised local contents, even in Semarang TV it is up to $90 \%$ of local contents. This local content is the flagship of all television stations so that it can still exist until today.

\section{Conclusion}

Based on the description stated previously, the following are some conclusions that can be drawn from this study. They are: first, the audiences segment targeted by local television is demographically adults who are 30 years and above. With the exception of TVKU Semarang, which targets the segment of the youth and student audiences. The excellent content presented for adult audiences over 30 years is news content that airs on prime time. In addition to news content, cultural and art contents are indeed favored by the adult segment aged 30 years and above. The example of cultural and art contents are 'wayang kulit' and 'ketoprak'. Second, local television does not make the current digital era as threat, but instead it is used as an opportunity to perform media convergence. The programs produced are then disseminated through digital media, internet.

Besides that, they also make an application that can be downloaded on a gadget so that it can be a branding that local television can also be global and keep up with the development of the digital era. Although in actual view it is not so encouraging, but at 
least it can be the starting point of optimism in facing competition with the increasingly tighter digital era today. Third, the concept of 'Think Global Act Local' does not seem to apply in the local television industry, on the contrary it becomes 'Think Local Act Global' for the broadcasting world if it wants to exist in the digital media. This concept is based on the idea that local television media in producing the broadcasts must think locally, but the action must be done globally by utilizing digital media. Media to act globally is the digital media itself. So the concept is how the contents with local spirit can be enjoyed by the global community.

\section{Acknowledgments}

This research was carried out thanks to funding from the Research and Community Service Institution (LPPM) IAIN Purwokerto, which was carried out in the 2018 budget year. Therefore the researcher thanked to LPPM IAIN Purwokerto for funding support during the research process and to the interviewees from five television stations in Central Java that were pleased to be interviewed amid the busy activities of managing television stations, they were Firdaus (Director of Banyumas TV), Deka (Marketing Manager of TVKU Semarang), Supriyadi (Director of Semarang TV), Rohman (Director of Simpang5 TV), and Daryanto (Operational Manager of Kebumen TV).

\section{References}

Badan Pusat Statistik. (2018). Penduduk Menurut Kelompok Umur, Daerah Perkotaan/ Perdesaan dan Jenis Kelamin Kabupaten Pati. Retrieved February 13, 2019, from 2018 http://sp2010.bps.go.id/index.php/site/tabel?tid=263\&wid=3318000000

website:

Berita Satu. (2010). Orang Indonesia 4,5 Jam Menonton TV Tiap Hari. Retrieved October 12, 2017, from 2010 website: http://www.beritasatu.com/budaya/19641-orangindonesia-4-5-jam-menonton-tv-tiap-hari.html

Cahayadi, M. L. (2017). Kebijakan Segmentasi Khalayak Program Siaran Talkshow Lembaga Penyiaran Swasta Televisi di Kota Makassar. Makassar: Universitas Hasanuddin Makassar.

Claretta, D. (2012). Televisi Swasta Jawa Timur dan Kuantitas Program Bermuatan Lokal: Studi Kasus Televisi Lokal di Surabaya. Jurnal Ilmu Komunikasi, 2(2).

Handayani, S. (2010). WEB TV Sebagai Media Alternatif Mengakses Informasi. Jurnal The Messenger, 2(1), 42-48. Retrieved from https://doi.org/http://dx.doi.org/10.26623/themessenger.v2i1.289

Jaya, S. R. L. (2016). Studi Deskriptif Kuantitatif Prokrastinasi Mahasiswa Fakultas Psikologi Universitas Sanata Dharma. Universitas Sanata Dharma.

Kasali, R. (1998). Membidik Pasar Indonesia: Segmentasi, Targeting dan Positioning (P. Utomo, Ed.). Jakarta: Gramedia Pustaka Utama.

Kementerian Komunikasi dan Informasi Republik Indonesia. (2017). Daftar Izin yang Sudah Diterbitkan oleh Menteri Kominfo Bulan Januari 2017. Retrieved July 18, 2019, from 2017 website: https://epenyiaran.kominfo.go.id/uploads/informasi/0cbaa5f1f556655a73af21555256731d .pd

Kertajaya, H. (2006). Hermawan Kertajaya on Segmentation Seri 9 Elemen Marketing. Bandung: Mizan Pustaka.

Malau, R. M. U. (2011). Khalayak Media Baru. Jurnal The Messenger, 2(2), 51-56. Retrieved from https://doi.org/http://dx.doi.org/10.26623/themessenger.v3i1.183 
Munanjar, A. (2017). Analisis Segmentasi Pasar dan Manajemen SDM Pada Program Gebyar BCA Net TV. Jurnal Komunikasi, 8(1), 56-63.

N.A., R. (2002). Eksistensi Televisi Lokal (Kasus: Eksistensi TVKU Dalam Kompetisi Industri Penyiaran). Semarang: Fisipol Universitas Diponegoro.

Nielsen. (2014). Nielsen: Konsumsi Media Lebih Tinggi di Luar Jawa. Retrieved October 12, 2017, from 2014 website: http://www.nielsen.com/id/en/pressroom/2014/nielsen-konsumsi-media-lebih-tinggi-di-luar-jawa.html

Prabowo, A. (2012). Era Penyiaran Digital: Pengembangan atau Pemberangusan TV Lokal dan TV Komunitas? Jurnal Komunikasi, 1(4), 301-314.

Priyowidodo, G. (2008). Menakar Kekuatan dan Keunggulan Industri Televisi Lokal Di Era Otonomi. Jurnal Ilmiah SCRIPTURA, 2(1), 56-62. https://doi.org/https://doi.org/10.9744/scriptura.2.1.56-62

Rosiatun, A. (2010). Analisis Segmentasi Pasar Pemirsa Program Berita Sore (Studi Kasus di Kecamatan Pangkah Kabupaten Tegal). Universitas Diponegoro.

Setiawan, Y. B. (2010). Tekanan Konglomerat Media Terhadap Individual Para Praktisi (Kasus Keberpihakan Pada Kandidat Melalui Pemberitaan TV One, ANTV dan Metro TV, Selama Masa Pencalonan Ketua Umum Partai Golkar 2009-2014). Jurnal The Messenger, 2(1), 49-60. Retrieved from https://doi.org/http://dx.doi.org/10.26623/themessenger.v2i1.281

Soffa, H. N. (2013). Pemaknaan Audiens Tentang Program Acara Mario Teguh Golden Ways Di Metro TV (Studi Resepsi pada Anggota Facebook Mario Teguh). Universitas Muhammadiyah Malang.

Sudarmawan, W. (2007). Peluang dan Tantangan Bisnis Televisi Lokal Paska Regulasi Televisi Berjaringan. Jurnal Komunikasi, 2(1), 235-242.

Sussman, S., \& Moran, M. B. (2013). Hidden addiction: Television. Journal of Behavioral Addictions, 2(3), 125-132. https://doi.org/https://doi.org/10.1556/JBA.2.2013.008

Wiska, M. A., \& Lukman, S. (2014). Perencanaan Strategik Media Televisi dalam Persaingan di Industri Media Televisi Lokal: Studi pada PT. Padang Media Televisi. Universitas Andalas. 